\title{
Metabolic Flux Balance Analysis of the Primary Metabolism for Hydrogen Production in Purple Non-sulfur Bacteria
}

Link to publication record in Manchester Research Explorer

\section{Citation for published version (APA):}

Chongcharoentaweesuk, P., Zhang, J., \& Mavituna, F. (2011). Metabolic Flux Balance Analysis of the Primary Metabolism for Hydrogen Production in Purple Non-sulfur Bacteria. In host publication: International Journal of Bioscience, Biochemistry and Bioinformatics (Vol. 1). International Academy Publishing.

\section{Published in:}

host publication

\section{Citing this paper}

Please note that where the full-text provided on Manchester Research Explorer is the Author Accepted Manuscript or Proof version this may differ from the final Published version. If citing, it is advised that you check and use the publisher's definitive version.

\section{General rights}

Copyright and moral rights for the publications made accessible in the Research Explorer are retained by the authors and/or other copyright owners and it is a condition of accessing publications that users recognise and abide by the legal requirements associated with these rights.

\section{Takedown policy}

If you believe that this document breaches copyright please refer to the University of Manchester's Takedown Procedures [http://man.ac.uk/04Y6Bo] or contact uml.scholarlycommunications@manchester.ac.uk providing relevant details, so we can investigate your claim.

\section{OPEN ACCESS}




\title{
Metabolic Flux Balance Analysis of the Primary Metabolism for Hydrogen Production in Purple Non-sulfur Bacteria
}

\author{
Pasika Chongcharoentaweesuk, Jiangdong Zhang, and Ferda Mavituna
}

\begin{abstract}
A metabolic model was constructed in matrix formalism for hydrogen production by the purple non-sulfur bacteria Rhodobacter sphaeroides involving 183 reactions and 153 metabolites. Assuming pseudo-steady state, mass balances were performed for each metabolite and the resulting equations were solved using optimization. The objective function was the maximization of the hydrogen production. The comparison of the experimental and computational results indicated the importance of light in hydrogen production.
\end{abstract}

Index Term-Hydrogen, Metabolic Flux Balance Analysis, Purple Non-sulfur Bacteria, Rhodobacter sphaeroides.

\section{INTRODUCTION}

Due to the continuously increasing high energy demands of the society and the finite nature of fossil fuels reserves, alternative energy sources are becoming exceedingly important. Hydrogen is a promising alternative fuel because it is clean and renewable. Furthermore, its energy content of $122 \mathrm{~kJ} / \mathrm{g}$ is 2.75 times greater than that of the hydrocarbon fuels [1]. Production of hydrogen by biological routes is the most attractive approach when compared to other methods of production such as water electrolysis, thermo-chemical processes and radiolytic processes as it is less energy-intensive and the overall $\mathrm{CO}_{2}$ emission is not harmful to the environment considering its life cycle analysis [2]. There are several microorganisms identified for hydrogen production and purple non-sulfur bacteria (PNB) such as Rhodobacter sphaeroides is a potential candidate. Rhodobacter sphaeroides is a gram-negative, anaerobic photoheterotrophic bacterium. Cells of Rhodobacter sphaeroides are ovoid, heart-shaped or short rods in defined media. Many occur in pairs, sometimes connected by a slender filament or tube [3]. After decades of research, there are still significant problems in hydrogen production that prevent industrial scale production from becoming a reality. These include low production levels and the difficulty of provision of sufficient light to the culture Metabolic flux analysis is a useful tool of metabolic engineering that can

Manuscript received June 26, 2011; revised July 23, 2011.

P. Chongcharoentaweesuk is with Chemical Engineering and Analytical Science School, University of Manchester, M13 9PL, UK (corresponding author to provide phone: +44 (0) 1613064369; fax: +44 (0) 1613069321; e-mail: pasika.chongcharoentaweesuk@postgrad.manchester.ac.uk).

F. Mavituna is with Chemical Engineering and Analytical Science School, University of Manchester, M13 9PL, UK (e-mail: ferda.mavituna@manchester.ac.uk).

J. Zhang was with Chemical Engineering and Analytical Science School, University of Manchester, M13 9PL, UK (e-mail: op342435@gmail.com). help with the development of novel strategies for hydrogen production. In our model, we investigated the importance of light in hydrogen production.

\section{MATERIALS AND METHODS}

\section{A. Microorganisms and culture conditions}

In this study, we used Rhodobacter sphaeroides strain NCIMB 8253 from NCIMB LTD (Aberdeen, Scotland). The organism was grown photo-heterotrophically with $7.5 \mathrm{mM}$ DL-malate as the carbon source and $12 \mathrm{mM}$ sodium glutamate as the nitrogen source in modified Biebl \& Pfennig medium [4], [5] as indicated in Table I. The liquid culture medium used for hydrogen production was exactly the same as the growth medium except the concentration of DL-malate and glutamate were $15 \mathrm{mM}$ and $2 \mathrm{mM}$ respectively.

TABLE I. COMPOSITION OF THE MODIFIED BIEBL AND PFENNIG MEDIUM USED FOR GROWTH AND MAINTENANCE OF R. SPHAEROIDES.

\begin{tabular}{|l|c|}
\hline \multicolumn{1}{|c|}{ Compound } & Amount (mg/l) \\
\hline $\mathrm{KH}_{2} \mathrm{PO}_{4}$ & 500 \\
\hline $\mathrm{MgSO}_{4} \cdot 7 \mathrm{H}_{2} \mathrm{O}$ & 200 \\
\hline $\mathrm{NaCl}$ & 400 \\
\hline $\mathrm{Yeast} \mathrm{extract}$ & 200 \\
\hline $\mathrm{CaCl}{ }_{2} \cdot 2 \mathrm{H}_{2} \mathrm{O}$ & 50 \\
& \\
\hline Fe-citrate & \\
& \\
\hline Vitamin $(\mathrm{B} 12)^{\mathrm{b}}$ & $5 \mathrm{ml}$ \\
\hline Trace element & \\
\hline
\end{tabular}

a) $0.1 \%$ wt./vol Fe-citrate, b) $1.0 \mathrm{mg} / 100 \mathrm{ml}$ Vitamin B12, c) $1 \mathrm{ml} / \mathrm{l}$ of the trace element solution was added containing the following chemicals (in mg/l): $\mathrm{ZnCl}_{2}, 70 ; \mathrm{MnCl}_{2} \bullet 4 \mathrm{H}_{2} \mathrm{O}$, $100 ; \mathrm{H}_{3} \mathrm{BO}_{3}, 60 ; \mathrm{CoCl}_{2} \bullet 6 \mathrm{H}_{2} \mathrm{O}, 200 ; \mathrm{CuCl}_{2} \cdot 2 \mathrm{H}_{2} \mathrm{O}, 20 ; \mathrm{NiCl}_{2}$ $6 \mathrm{H}_{2} \mathrm{O}, 20 ; \mathrm{NaMoO}_{4} \cdot 2 \mathrm{H}_{2} \mathrm{O}, 40 ; \mathrm{HCl}(25 \% \mathrm{v} / \mathrm{v}), 1 \mathrm{ml} / 1$.

Cells were grown anaerobicly by using argon gas to create an anaerobic environment at $30^{\circ} \mathrm{C}, \mathrm{pH} \mathrm{6.8}$, and under the illumination of a 3000 lux tungsten lamp. The initial $\mathrm{pH}$ value of all the media was adjusted to around 6.8 using $1 \mathrm{M}$ $\mathrm{NaOH}$ solution. 

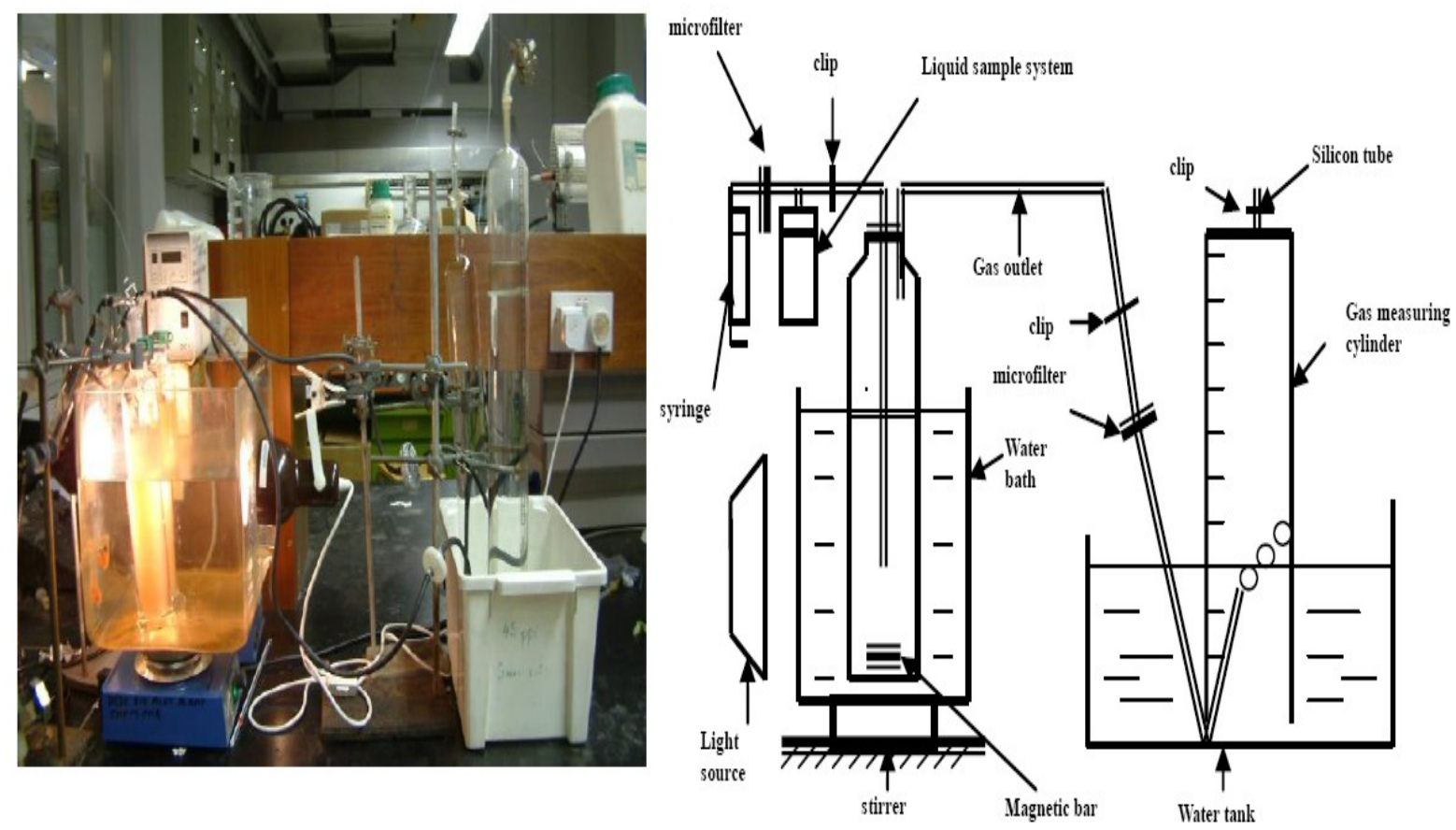

Fig. 1 The glass column photobioreactor used for hydrogen production.

\section{B. Photobioreactor system}

The experiments of hydrogen production were carried out in a $1 \mathrm{~L}$ glass column photobioreactor with a working volume of $600 \mathrm{ml}$. The inoculum was $10 \% \mathrm{v} / \mathrm{v}$. The diameter of the vessel was $6 \mathrm{~cm}$. The glass lid had three ports used for sampling, inoculation and hydrogen gas collection.

The temperature was controlled at $30{ }^{\circ} \mathrm{C}$ using a water bath. The photobioreactor was operated with an agitation of $140 \mathrm{rpm}$ using a magnetic stirrer.

\section{Methods of analysis}

Bacterial growth was measured at $660 \mathrm{~nm}$ using JENWAY 6305 UV/VIS Spectrophotometer. The biomass dry weights were determined by measuring cell dry weight using a standard calibration curve (cell dry weight, g/l against optical density measurement at $660 \mathrm{~nm}$ ). The biomass dry weights were determined using the same samples by centrifuging in the plastic tubes $(10 \mathrm{ml})$ at 4000rpm for 15 minutes using IECCentra-3M centrifuge. The supernatants were discarded and the cells were dried in pre-weighed small vials for 24 hours. It was found that the optical density (OD) of 1 at $660 \mathrm{~nm}$ corresponded to the cell density of $0.5076 \mathrm{~g}$ dry weight per liter culture.

The evolved hydrogen was analyzed using a Gas Chromatograph (GC). HPLC analyses were used to monitor the concentration of DL malate and sodium glutamate. The supernatant samples (from IECCentra-3M centrifuge) were analyzed by HYPERSIL $(250 \times 4.6 \mathrm{~mm}, 5 \mu)$ BDS C8 column at a pressure of $94 \mathrm{~atm}$ with $0.05 \mathrm{M}$ phosphoric acid as a mobile phase at a flowrate of $0.7 \mathrm{ml} / \mathrm{min}$. For the construction of the standard calibration curves, DL malate and sodium glutamate with different concentrations were analyzed first in order to obtain their retention times.

The $\mathrm{pH}$ of the culture medium was measured using Corning $\mathrm{pH} /$ ion meter 155.

\section{In silico model construction and metabolic flux balance analysis (MFA)}

The anaerobic metabolic network for purple non-sulfur bacteria (PNB) was reconstructed in matrix formalism from the information available on Rhodobacter sphaeroides in the literature, the KEGG metabolic pathways database and standard biochemistry textbooks. The main assumption of this model is that, the metabolic fluxes are at pseudo-steady state and the metabolite concentrations remain constant. This can be justified considering the homeostasis [6]. The steady-state balance equation is written [7] as

$$
\mathbf{S . v}=\mathbf{b}
$$

where $\mathbf{S}$ is the stoichiometric matrix, $\mathbf{v}$ is the vector of fluxes, and $\mathbf{b}$ is the vector of net specific transport rates from the cell.

The computational approach then involves making material balances around each metabolite and solving the resulting equations for the unknown fluxes using optimization with the experimental and biological constraints. The optimization is needed because since each metabolite usually takes part in more than one reaction and therefore the number of unknown (metabolic fluxes) are greater than the number of equations (the mass balance equations for each metabolite). The metabolic network of Rhodobacter sphaeroides was constructed to conatin 183 reactions and 153 metabolites. The summary of the overall metabolic pathway is shown in Fig. 2.

The list of simulated metabolic pathways include glycolysis/gluconeogenesis, pentose phosphate pathway, pyruvate metabolism, tricarboxylic acid (TCA) cycle, electron transport, amino acid biosynthesis, nucleic acid biosynthesis, fatty acid biosynthesis, PHB biosynthesis, phospholipid biosynthesis, carbohydrate biosynthesis, transhydrogenase reactions, DNA and RNA polymerisation, protein biosynthesis, transport reactions and biomass formation. 


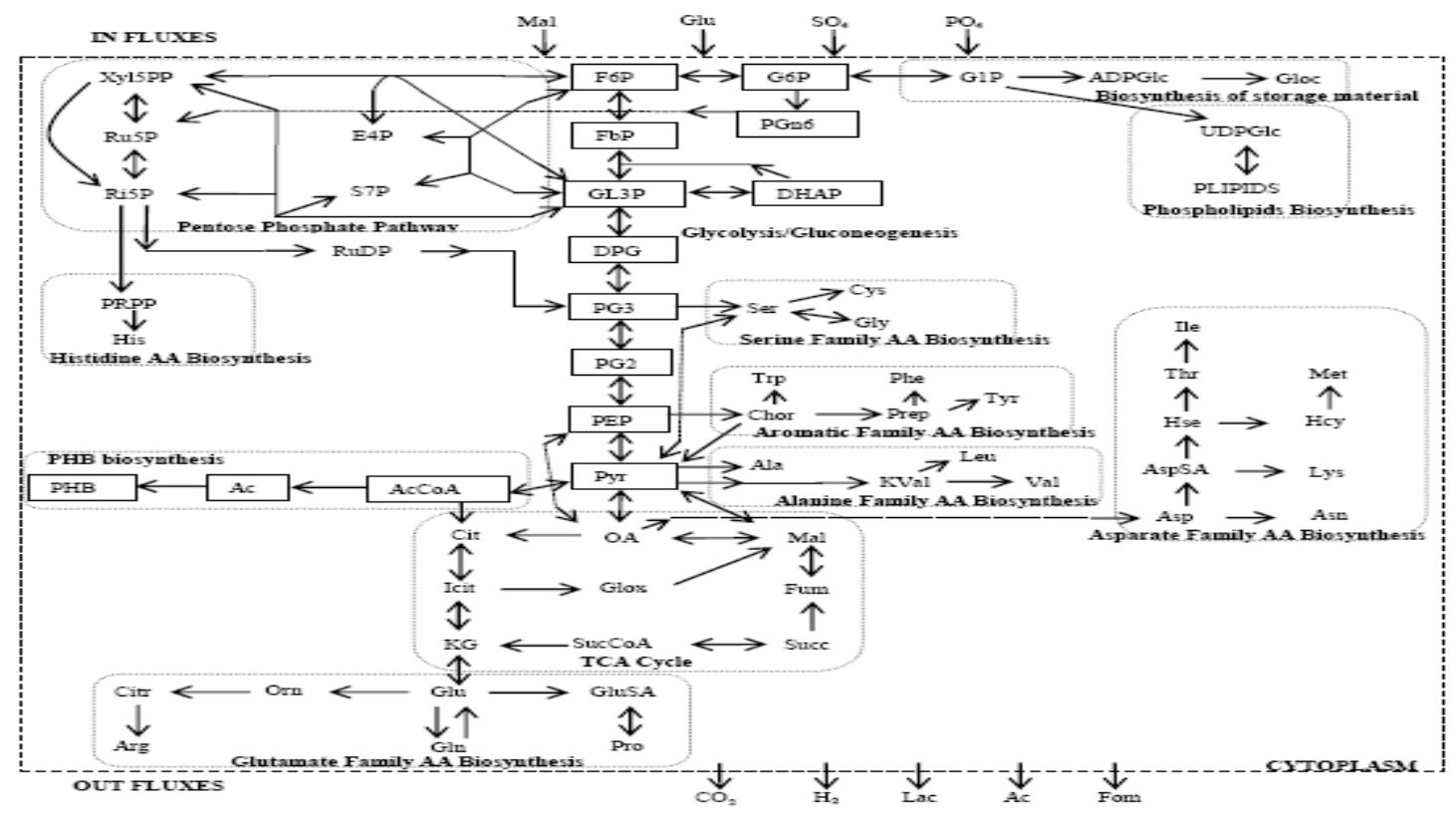

Fig. 2 The overall metabolic network of Rhodobacter sphaeroides used for the hydrogen production model

Biomass is assumed to consist mainly of proteins, carbohydrates, RNA, DNA and phospholipids. The percentages of protein, carbohydrates, RNA, DNA and phospholipids are assumed to be the same as E. coli [8]. The polymerisation energies required for protein, RNA and DNA are also taken from E. coli [8].

In this study, the metabolic model was constructed for the dark anaerobic condition. Therefore, no photosynthetic reactions were involved in this metabolic flux analysis.

This was to test whether the purple non-sulfur bacteria (PNB) such as Rhodobacter sphaeroides could grow and produce hydrogen gas under the anaerobic dark conditions in silico.

\section{E. Objective functions of the model}

The main input parameters of this model are the specific consumption rates of DL malate and sodium glutamate. The objective function for the optimization was either the maximization of the specific cell growth rate or the specific hydrogen production rate.

\section{F. Software}

The linear programming problem was solved using General Algebraic Model System (GAMS) software (http://www.gams.com/). The solution not only gives the value of the objective function but also the values of all the metabolic fluxes.

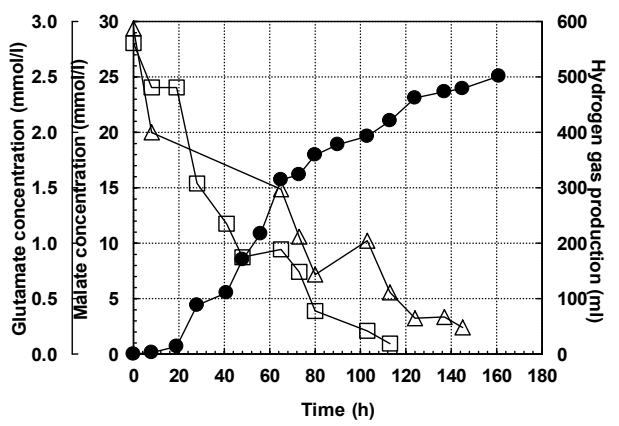

Fig. 3 Malate consumption $(\square)$, Glutamate consumtion $(\Delta)$ and hydrogen gas production $(\bullet)$ by Rhodobacter sphaeroide in the $1 \mathrm{~L}$ bioreactor.

\section{RESULTS AND DISCUSSION}

A uniform light intensity of 4-9 W/m $/ \mathrm{m}^{2}$ for cell growth and the light intensity of $9-15 \mathrm{~W} / \mathrm{m}^{2}$ for optimal hydrogen production in anoxic environment has been reported [9], [10]. The experiment of the hydrogen production was performed under the light intensity of $4 \mathrm{~W} / \mathrm{m}^{2}$, provided by a tungsten lamp. DL malate, glutamate concentration and hydrogen production during batch culture of R. sphaeroides are presented in Fig 3. From the experiment results, specific rates were calculated and were then used as input data such as DL malate and glutamate consumption and for comparison, such as the specific hydrogen production rate.

The metabolic model was constructed for the anaerobic dark condition. Fig. 4 shows the comparison of hydrogen production obtained from the experimental and computational results where the hydrogen produced in both cases increased until cell growth reached the stationary stage.

Hydrogen production is associated with hydrogenase and nitrogenase enzymes however, hydrogen production activity of nitrogenase is provided by the photosynthetic apparatus, which converts light energy into chemical bond energy (ATP). In the dark, hydrogen gas is generated via formate-hydrogen lyase (FHL) complex where formate is oxidized to carbon dioxide as well as releasing hydrogen with the regeneration of $\mathrm{NAD}^{+}$required for the redox balance during fermentative growth [11].

As indicated in Fig 4, the computational hydrogen production rate was lower than the experimental result.

This has proven that hydrogen production by purple non-sulfur bacteria is mainly correlated with the activity of nitrogenase.

The comparison of the experimental and computational results in Fig 5 indicates that the metabolic model predicts lower specific growth rates except for the late stages of the fermentation.

Hydrogen evolution started at 10 which shows that 
hydrogen is produced from mid to late exponential growth phase.

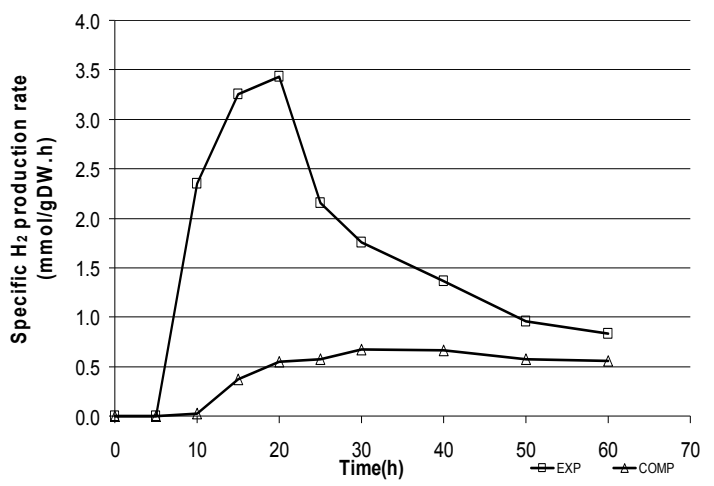

Fig. 4 Comparison of experimental and computational specific hydrogen production rates during the batch culture.

During the exponential growth (5-20 h), DL-malate (organic carbon) was used for the generation of $\mathrm{NADH}$ via oxidation into carbon dioxide in the tricarboxylic acid (TCA) cycle and also for the biosynthesis of biosynthetic pathways (amino acid, nucleic acid, fatty acid, PHB, phospholipid, carbohydrate and protein synthesis). The electron extracted from the oxidation of malate is directed towards hydrogen. In the stationary phase $(20-40 \mathrm{~h})$, most of the DL malate is oxidized into carbon dioxide which means that biosynthesis is minimal. Therefore most of the extracted electrons are directed towards hydrogen.

Although the model included the biosynthesis of poly-3-hydroxybutyric acid (PHB), there was no flux towards this by-product formation in the computed results. This was because there was not enough NADH which was generated from the carbon source (malate) to synthesise PHB and no abundant energy from the nitrogenase complex.

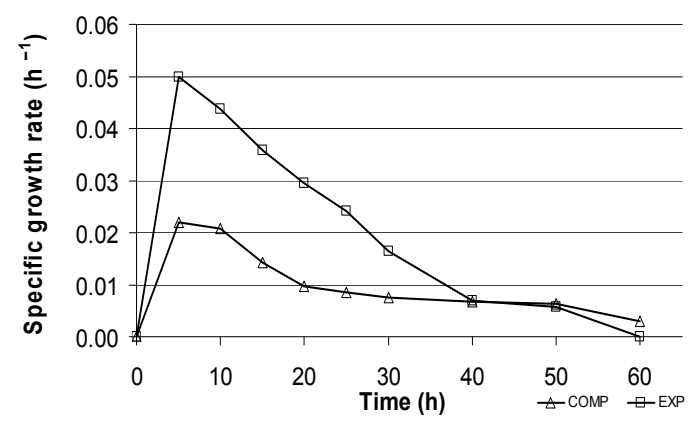

Fig. 5 Comparison of experimental and computational growth rates during the batch culture.

\section{CONCLUSIONS}

The comparison of experimental and computational results indicates that the metabolic model predicts lower specific rates of hydrogen production. We can conclude that the nitrogenase synthesis, which plays a significant role in hydrogen formation, is strongly stimulated by light and therefore the in silico production of hydrogen in the dark would be inferior to the production in the light. The metabolic model can further be developed to include the light influenced reactions and subsequently to identify the metabolic bottlenecks in biological hydrogen production so that process and genetic engineering strategies can be developed.

\section{REFERENCES}

[1] K. I. Kapdan and F. Hargi, "Bio-hydrogen production from waste materials", Enzyme and Microbial Technology, 2006, 38, pp. 569-582.

[2] P. C. Hallenbeck and J. R. Benemann. "Biological hydrogen production; fundamentals and limiting processes", International Journal of Hydrogen Energy, 2002, 27, pp. 1185-93.

[3] N. B. Pellerin and H. Gest. "Diagnostic features of the photosynthetic bacterium Rhodopseudomonas sphaeroides", Current Microbiology, 9, pp. 339-344.

[4] H. Biebl and N. Pfennig. "Isolation of member of the family Rhodosprillacaea", The Prokaryotes. New York: Springer-Verlag, 1981, pp. 267-273.

[5] N. Basak and D. Das. "Photofermentation hydrogen production using purple non-sulfur bacteria Rhodobacter sphaeroides O.U.001 in an annular photobioreactor: A case study" Biomass and Bioenergy, 2009, 33, pp. 911-919.

[6] G. N. Stephanopoulos, A. A. Ariatidou and J. Nielsen. "Application of Metabolic Flux Analysis”, Metabolic Engineering. San Diego. Academic Press, 1998, pp. 411-459.

[7] J. M. Savinell and B. O. Palsson. "Network analysis of intermediary metabolism using liner optimization I. Development of mathematical formalism", J. Theor. Biol., 154, pp.421-454.

[8] J. L. Ingraham, O. Maaloe and F. C. Neidhardt. Growth of the Bacteria Cell. Sinauer Associates. Sunderland, MA. 1983.

[9] N. Basak and D. Das. "The prospect of purple non-sulfur (PNS) photosynthetic bacteria for hydrogen production: the present state of art”, World J Microbiol Biotechnol, 2007, 23, pp. 31-34.

[10] J. Miyake and S. Kawamura. "Efficiency of light energy conversion to hydrogen by photosynthetic bacteria Rhodobacter sphaeroides", Int J Hydrogen Energy, 1987, 12, pp. 147-149.

[11] H. Koku, I. Eroglu, U. Gunduz, M. Yucel and L. Turker. "Aspects of the metabolism of hydrogen production by Rhodobacter sphaeroides", International Journal of Hydrogen Energy. 2002, pp. 1315-1329.

Pasika Chongcharoentaweesuk, biography and photograph not available at the time of publishing.

Jiangdong Zhang, biography and photograph not available at the time of publishing.

Ferda Mavituna, biography and photograph not available at the time of publishing. 